\title{
Jolele
}

\section{THE EMPIRICAL STUDY OF EXTRACURRICULAR ACTIVITY ON SOCIALLY RESPONSIBLE LEADERSHIP}

\section{Abstract}

This study examines how extracurricular activity experiences affect students' leadership development outcomes. Students' leadership development outcomes are analyzed depend on general characteristics and collegiate/pre-collegiate experiences of extracurricular activities. The correlation to the individual, group, and community values of leadership development was analyzed. The study utilized the Social Change Model and Socially Responsible Leadership Scale (SRLS-R2). Data was analyzed from college students (N=706) using quantitative methodology. The results indicated students who participated in extracurricular activities while in college and high school scored relatively higher in each individual, group, and community value ( $p<.05)$. Gender and class level were significantly associated with student leadership development. Specifically, women had relatively higher leadership development than men in congruence, commitment, and citizenship. Also, senior students scored higher than sophomores in individual and community values, showing significant differences. This study guides educational leaders to amplify student participation opportunities that positively affect their leadership development. Educators should consider multifaceted approaches to enhance students' leadership and a substantively deeper understanding of the latent benefits and patterns of student involvement in extracurricular activities.

Keywords: Extracurricular activity; Gender; Pre-collegiate experiences; Leadership development; Social Change Model; Socially responsible leadership

\section{Introduction}

Experiences in extracurricular activities are an important part of campus life. Identifying and marketing specific leadership learning outcomes help students know how an activity enhances their leadership development. These initiatives serve as a valuable means for integrating intentional leadership outcomes into activities designed to enhance leadership among all students.
Several researchers discovered a relationship between extracurricular participation and leadership outcomes (Astin, 1999; Ewing et al., 2009; Foreman \& Retallick, 2013; Hancock et al., 2012; Simonsen et al., 2014). However, little research explored how collegiate and pre-collegiate experiences of extracurricular activity impacted the outcomes of students' leadership development regarding all individual, group, and community values for the Social Change Model (SCM).

The purpose of this study is to explore how 
extracurricular organization experiences affect student leadership development. Independent variables were defined based on their demographic and participation experiences in extracurricular activities while in college and high school. Dependent variables were be identified at the individual, group, and society/community levels of leadership development outcomes.

This study includes three research areas. First, leadership development outcomes were identified by general characteristics such as gender and class level. Second, collegiate and pre-collegiate remembered experiences of extracurricular organizations/ clubs were analyzed on leadership development outcomes. Third, the study analyzed the correlation between general characteristics, pre-collegiate, and collegiate experiences as well as all individual, group, and community values of leadership development outcomes.

\section{Conceptual Framework}

The social change model of leadership (SCM, Higher Education Research Institute, 1996) was created specifically for college students. The SCM of leadership development has the individual, group, and society/community values level (figure 1). Under each level, SCM identifies seven core values that include the consciousness of self, congruence, commitment for individuals; collaboration, common purpose, controversy with civility for groups; and citizenship for societies (Astin \& Astin, 1996).
Figure 1.

Social Change Model of Leadership

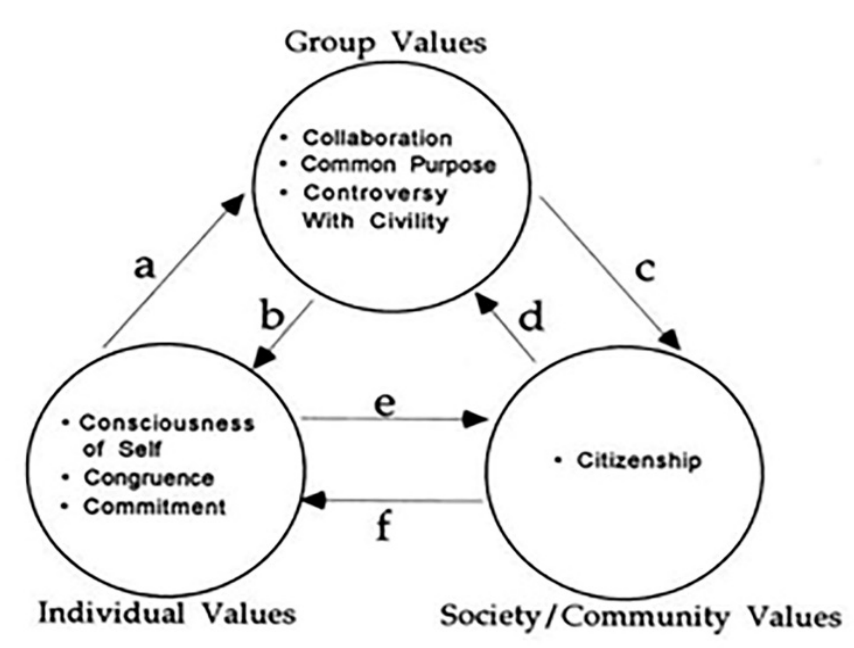

Note. Adapted from a social change model guidebook version III, Higher Education Research Institute, 1996, p. 19.

These values represent a student's leadership knowledge and capacity and contribute to community change for the common good. Social change can be reached through the purpose-driven, collaborative, value-based approach to leadership taken by this model (Dugan \& Komives, 2007; Komives et al., 2009; Foreman \& Retallick, 2013).

Leadership development was assessed using the Socially Responsible Leadership Scale (SRLS-R2). The scale includes 68 Likert-type items, which includes eight separate scales that measure three specific constructs of the Social Change Model (SCM). These constructs are divided into three value levels. As each value begins with the letter $C$, these have come to be known as the "Seven C's." Since change is an assumption of the model as well, the SRLS-R2 also measures the value of "change." In addition, SRLS-R2 Omnibus was used to measure the overall construct of leadership development. SCM core values are further explained in the following table (Table 1). 
Table 1

Seven C's: The Critical Values of the Social Change Model

\begin{tabular}{|c|c|}
\hline Individual Values & \\
\hline $\begin{array}{l}\text { Consciousness of } \\
\text { Self }\end{array}$ & $\begin{array}{l}\text { Being self-aware of the beliefs, values, attitudes, and emotions that motivate you to take action. } \\
\text { Being mindful, or aware of your current emotional state, behavior, and perceptual lenses. }\end{array}$ \\
\hline Congruence & $\begin{array}{l}\text { Acting in ways that are consistent with your values and beliefs. Thinking, feeling, and behaving } \\
\text { with consistency, genuineness, authenticity, and honesty toward others. }\end{array}$ \\
\hline Commitment & $\begin{array}{l}\text { Having significant investment in an idea or person, both in terms of intensity and duration. Having } \\
\text { the energy to serve the group and its goals. Commitment originates from within, but others can } \\
\text { create an environment that supports an individual's passions. }\end{array}$ \\
\hline Group Values & \\
\hline Collaboration & $\begin{array}{l}\text { Working with others in a common effort, sharing responsibility, authority, and accountability. } \\
\text { Multiplying group effectiveness by capitalizing on various perspectives and talents, and on the } \\
\text { power of diversity to generate creative solutions and actions. }\end{array}$ \\
\hline Common Purpose & Having shared aims and values. Involving others in building a group's vision and purpose. \\
\hline $\begin{array}{l}\text { Controversy with } \\
\text { Civility }\end{array}$ & $\begin{array}{l}\text { Recognizing two fundamental realities of any creative effort: 1) that differences in viewpoint are } \\
\text { inevitable, and 2) that such differences must be aired openly but with civility. }\end{array}$ \\
\hline Community valt & \\
\hline Citizenship & $\begin{array}{l}\text { Believing in a process whereby an individual and/or a group become responsibly connected to the } \\
\text { community and to society through some activity. Recognizing that members of communities are } \\
\text { not independent, but interdependent. Recognizing individuals and groups have responsibility for } \\
\text { the welfare of others. }\end{array}$ \\
\hline Change & $\begin{array}{l}\text { Believing in the importance of making a better world and a better society for oneself and others. } \\
\text { Believing that individuals, groups, and communities have the ability to work together to make that } \\
\text { change. }\end{array}$ \\
\hline
\end{tabular}

Note. Adapted from a social change model guidebook version III, Higher Education Research Institute, 1996, p.21, used with permission from the National Clearinghouse for Leadership Programs

\section{Review of Literature}

\section{Demographics \& Pre-college Characteristics.}

Demographic characteristics have been studied and shown to be significant (Buschlen \& Johnson, 2014; Pascarella \& Terenzini, 2005) on college students' leadership development. Gender has been shown to support students' leadership development (Eagly, 2007; Haber, 2012; Rost, 1991). According to Buschlen and Johnson (2014), gender does mediate students' capacities for collaboration and citizenship. These findings support earlier research suggesting gender differences in leadership development (Eagly, 2007; Haber, 2012).

Kezar and Moriarty (2000) suggest both gender differences and the need to better align students' capacities with their sense of efficacy provide direction for targeting developmental interventions with college women and men. Zacherman and 
Foubert (2014) indicate that women seem to perform better academically when they are in co-curricular activities. This disparity showed that student affairs practitioners must be cognizant of how hours spent in student organizations impacted the development of men and women differently. Additionally, the SRLS was used in comparing gender differences in SCM outcomes (Dugan, 2006a; Haber \& Komives, 2009). The Research by Pascarella and Terenzini (2005) pointed out that upperclassmen tended to report higher leadership development outcomes than their first-year counterparts.

The main contributor to empirical knowledge, Astin (1984), indicated that environmental influences affected student development. This theory offers a foundation for the potential benefits of pre-college student participation in leadership development activities. He proposed College Impact Models, which have come to be known as the Inputs-EnvironmentOutcome (I-E-O) Model. The IEO Model controls what a student brings to campus such as demographics or pre-college experiences and examines proximal aspects of the environment such as the amount of involvement, leadership training, and discussions of socio-cultural issues. The IEO Model also predicts various leadership outcomes (Strayhorn, 2008). The principal advantage of the student involvement theory over traditional pedagogical approaches shifts from subject matter and technique toward students' motivation and behavior. It views student time and energy as institutional resources, although limited. Thus, most institutions changed the evaluation frame of policies and practices to increase students' involvement.

Simonsen et al. (2014) determined the relationship between student activity participation and leadership characteristics. This study revealed that incoming college students participated more in community service and athletics than any other activities during their high school experience. The strongest positive relationship with high school activity participation was in leadership efficacy, sociability, and charisma constructs. Students' pre-college leadership knowledge and skills are among the strongest predictors of their leadership capacity and efficacy (Komives et al., 2011). For this reason, colleges partnering with local schools to implement a peer leadership program could synergize both college students and high school students.

College Student Leadership. Leadership experience includes any time that students are responsible for a project or for guiding, motivating, or instructing others. Institutions of higher education desire student leadership abilities because they expect students in college leadership roles to make differences on a larger scale in academia and research in the future. Boatman (1999) points out that colleges use both formal (instruction) and informal (extracurricular) methods to enhance student leadership abilities. Accordingly, showing that students have the sense of responsibility that leaders require can be very attractive to such institutions. In this way, undertaking a leadership role helps students stand out from the group.

Astin (1993) addressed that elected student offices, public-speaking ability, leadership ability, and interpersonal skills were all correlated with the hours per week spent in student organizations. Serving as an officer is also associated with spending more time participating in extracurricular clubs and organizations. Both independent variables were related to increased leadership development. Undergraduate students who acted as team leaders also showed higher scores on the group and societal values of the SRLS (Dugan, 2006b). Similar findings have been reported concerning the impact of serving as a club officer on a student's initiative, and the perception of belonging to the organization had a positive impact on leadership development (Rubin et al., 2002; Ewing et al., 2009). College graduates self-reported that extracurricular leadership roles significantly impacted their development of leadership skills and interpersonal abilities that improve their work performance (Smith \& Chenoweth, 2015).

According to Hannah et al. (2008), leadership efficacy is the belief that an individual possesses the skills 
and abilities needed to lead. This ability to facilitate the decision-making process and implement action is an important function of effective leadership. A leader must also be able to produce results, influence action, facilitate change, and build others. Simonsen et al. (2014) noted that the characteristics of leadership decision-making efficacy, the leader's ability to determine and communicate decisions, are viewed as components of effective leadership.

Extracurricular Activity. Extracurricular activities are available to all college students. They typically take place on campus, but they are optional and do not interfere with their required courses. Extracurricular activities can include social clubs, sports teams, student government positions, volunteer experiences, or even internships (World Education Services, 2019). Different types of extracurricular activities provide distinct patterns of experiences. Linver et al. (2009) found that sports involvement impacted males and females differently. Females were more likely to be in various organizations such as sports, schools, and religious groups while males were more likely to only participate in sports and be less involved in other clusters.

For relational leadership behaviors, students active in co-curricular organizations also assess themselves significantly more positively on having strong people skills, as serving as a model for others, dealing effectively with failure, dealing well with stress, resolving conflict, communicating clearly, working effectively in teams, and being a good listener (Smith \& Chenoweth, 2015). As a result, this study indicated that students involved in student organizations rate their leadership behaviors higher than those who do not engage in school organizations.

The importance of participation in student organizations to develop leadership skills has also been reported in several studies. Rutherford et al. (2002) concluded that everyone can be a leader, but individuals do not possess all the skills or expertise to always lead. Birkenholz and Schumacher (1994) found that participation in multiple extracurricular activities positively influenced perceived leadership skills (as cited in Ewing et al., 2009).

Extracurricular sports activities showed that those who were assisting as a leader in more than one sports activity meaningfully indicated having a more positive awareness of their leadership ability (Hancock et al., 2012). Informal, non-academic settings contributed substantially to students' career skills, according to self-reports and ratings of skills (Pascarella \& Terenzini, 2005). When college students were engaged in social aspects of campus life, they advanced their learning and their personal development, and the relationship between academic success and co-curricular involvement (Huang \& Chang, 2004).

Pascarella and Terenzini (2005) and Rubin et al. (2002) analyzed an extracurricular index score such as the number of clubs, the role of officers, and the hours spent. In Foreman and Retallick's (2013) study, they suggested that the quality of involvement is more important than how much time students participate. Extracurricular leadership correlated to higher scores in the individual value categories of the social change model. Consequently, the improved capabilities often related to serving as an officer may be correlated with more opportunities to obtain leadership training. Both kinds of research showed that the combination of frequency and quality of students' involvement was linked to higher rates of leadership and interpersonal skills.

\section{Methodology}

Data Collection. The target population of this study is undergraduate college students from Eastern Kentucky University, Berea College, and the University of Kentucky. To learn more about the students' extracurricular experiences, a purposive sampling technique was used. As a non-probability sampling method, Black (2010) defines the purposive sampling method that allows the researcher a choice of elements selected for the sample. Thus, 
the study surveys students who are upperclassmen and have more opportunities to be involved in extracurricular activities. Contact email information for these students was received from the university registrar's office and institutional research center. After eliminating incomplete data and response set errors, 706 data samples were analyzed.

Instrumentation. The survey combined existing instruments for leadership development outcomes and the researcher-designed questions about extracurricular activity experiences. Following the study's conceptual framework, the instrument was organized into collegiate experiences, leadership development, and pre-collegiate experiences. The questionnaire was tested before collecting data. Pretesting and piloting identified survey questions that did not make sense to participants, or problems with the questionnaire that might lead to biased answers.

The reliability of each SRLS-R2 scale was computed for this study using Cronbach's alpha. It was found to be similar to 0.7 or higher in community values of SRLS-R2, which satisfied the confidence level. The study obtained permission to use it for this research. Facevalidity, content validity, and internal validity were established by a group of students similar to those in the sample. Expert panels of staff and faculty who have experience as leaders in the extracurricular/cocurricular activity/student organizations viewed the survey. A group of doctoral students and professors were asked for their input regarding face validity. After careful consideration of the suggestions of both student panels and the professional panel, changes were made to the instrument, including both content and question format.

Data Analyses. Survey responses were automatically recorded by Qualtrics as subjects completed an IRB-approved survey. Once data collection was completed, raw data was checked for missing data and obvious errors. Incomplete data and response set errors were documented and eliminated from the dataset. The SPSS (Version 24) program was used to analyze the data. A t-test and ANOVA were calculated to determine if there were mean differences in the dependent variables: gender, class level, and collegiate/pre-collegiate experiences of extracurricular organizations/clubs based on the independent variables of leadership development outcomes (SRLS-R2) and the Scheffe test was performed as a post-test.

Correlation analysis was used to identify the relationship between related variables. This is indicated the correlations respectively between several variables: high school extracurricular participation, college extracurricular participation, and individual, group, community values of leadership development outcomes.

\section{Results}

General Characteristics. To examine the difference in the mean of leadership development by general characteristics such as gender and class level, a t-test and one-way ANOVA were conducted, and the Scheffe test was performed as a post-test.

Gender. Women scored higher than men in the congruence and commitment, which showed significant differences ( $p<.05$, table 2$)$. When it came to citizenship, women scored relatively higher than men $(p<.05)$. Overall, it can be seen that the difference in leadership development (SRLS-R2) according to gender is not significant. 
Table 2

Differences in Leadership Development (SRLS-R2) by Gender

\begin{tabular}{|c|c|c|c|c|c|c|}
\hline & Q1 & $\mathbf{N}$ & M & SD & $\mathbf{F}$ & $p$ \\
\hline \multirow{2}{*}{ Consciousness of Self } & Male & 186 & 3.84 & .55 & \multirow{2}{*}{.996} & \multirow{2}{*}{.319} \\
\hline & Female & 517 & 3.79 & .50 & & \\
\hline \multirow{2}{*}{ Congruence } & Male & 186 & 4.12 & .55 & \multirow{2}{*}{$-2.970^{* *}$} & \multirow{2}{*}{.003} \\
\hline & Female & 517 & 4.24 & .47 & & \\
\hline \multirow{2}{*}{ Commitment } & Male & 186 & 4.32 & .50 & \multirow{2}{*}{$-3.105^{* *}$} & \multirow{2}{*}{.002} \\
\hline & Female & 517 & 4.44 & .46 & & \\
\hline \multirow{2}{*}{ Individual Values Total } & Male & 186 & 4.06 & .47 & \multirow{2}{*}{-1.529} & \multirow{2}{*}{.127} \\
\hline & Female & 517 & 4.11 & .41 & & \\
\hline \multirow{2}{*}{ Collaboration } & Male & 186 & 4.07 & .49 & \multirow{2}{*}{-.969} & \multirow{2}{*}{.333} \\
\hline & Female & 517 & 4.11 & .43 & & \\
\hline \multirow{2}{*}{ Common Purpose } & Male & 186 & 4.06 & .50 & \multirow{2}{*}{-1.379} & \multirow{2}{*}{.168} \\
\hline & Female & 517 & 4.11 & .41 & & \\
\hline \multirow{2}{*}{ Controversy with Civility } & Male & 186 & 3.92 & .45 & \multirow{2}{*}{-.275} & \multirow{2}{*}{.783} \\
\hline & Female & 517 & 3.93 & .43 & & \\
\hline \multirow{2}{*}{ Group Values Total } & Male & 186 & 4.01 & .42 & \multirow{2}{*}{-.955} & \multirow{2}{*}{.340} \\
\hline & Female & 517 & 4.04 & .36 & & \\
\hline \multirow{2}{*}{ Citizenship } & Male & 186 & 4.01 & .59 & \multirow{2}{*}{$-2.387^{*}$} & \multirow{2}{*}{.017} \\
\hline & Female & 517 & 4.13 & .52 & & \\
\hline \multirow{2}{*}{ Change } & Male & 186 & 3.86 & .48 & \multirow{2}{*}{1.540} & \multirow{2}{*}{.124} \\
\hline & Female & 517 & 3.80 & .51 & & \\
\hline \multirow{2}{*}{ community values Total } & Male & 186 & 3.93 & .48 & \multirow{2}{*}{-.330} & \multirow{2}{*}{.742} \\
\hline & Female & 517 & 3.94 & .45 & & \\
\hline Omnihus total & Male & 186 & 4.00 & .41 & -1047 & 296 \\
\hline Umnious total & Female & 517 & 4.04 & .36 & $-1.04 /$ & .296 \\
\hline
\end{tabular}

${ }^{*} p<.05,{ }^{* *} p<.01,{ }^{* * *} p<.001$

Class Level. At the class level, first-year/freshmen and seniors/others scored high in the total of the individual values, and sophomores and juniors scored relatively low, showing a significant difference $(p<.05$, Table 3 ). The consciousness of self, a sub-variable of individual values, was a significant difference, indicating that seniors/others were high, and the sophomores were relatively low $(p<.05)$. In the group values total, there was no significant difference. In the community values total, seniors/others and juniors were relatively high, and first-year/freshmen and sophomores were relatively low, showing a significant difference $(p<.05)$.
The difference in leadership development (SRLS-R2) according to the class levels was significant, and seniors/others, juniors, and first-year/freshmen were relatively high, and the sophomores were relatively low. 
Table 3

Differences in Leadership Development (SRLS-R2) by Class Level

\begin{tabular}{|c|c|c|c|c|c|c|c|}
\hline & & $\mathbf{N}$ & $M$ & SD & $F$ & $p$ & scheffe \\
\hline \multirow{5}{*}{ Consciousness of Self } & $\begin{array}{l}\text { First-year/ } \\
\text { freshman(a) }\end{array}$ & 39 & 3.79 & .53 & \multirow{5}{*}{$7.279^{* \star *}$} & \multirow{5}{*}{.000} & \multirow{5}{*}{$d>a, c>b$} \\
\hline & Sophomore(b) & 135 & 3.65 & .46 & & & \\
\hline & Junior(c) & 161 & 3.76 & .55 & & & \\
\hline & Senior/Other(d) & 371 & 3.88 & .51 & & & \\
\hline & Total & 706 & 3.80 & .52 & & & \\
\hline \multirow{5}{*}{ Congruence } & First-year/freshman & 39 & 4.31 & .47 & \multirow{5}{*}{1.742} & \multirow{5}{*}{.157} & \\
\hline & Sophomore & 135 & 4.14 & .48 & & & \\
\hline & Junior & 161 & 4.20 & .53 & & & \\
\hline & Senior/Other & 371 & 4.23 & .48 & & & \\
\hline & Total & 706 & 4.21 & .49 & & & \\
\hline \multirow{5}{*}{ Commitment } & First-year/freshman & 39 & 4.44 & .41 & \multirow{5}{*}{.912} & \multirow{5}{*}{.435} & \\
\hline & Sophomore & 135 & 4.35 & .49 & & & \\
\hline & Junior & 161 & 4.43 & .51 & & & \\
\hline & Senior/Other & 371 & 4.42 & .46 & & & \\
\hline & Total & 706 & 4.41 & .48 & & & \\
\hline \multirow{5}{*}{ Individual Values Total } & $\begin{array}{l}\text { First-year/ } \\
\text { freshman(a) }\end{array}$ & 39 & 4.13 & .40 & \multirow{5}{*}{$3.968^{* *}$} & \multirow{5}{*}{.008} & \multirow{5}{*}{$a, d>b, c$} \\
\hline & Sophomore(b) & 135 & 4.00 & .38 & & & \\
\hline & Junior(c) & 161 & 4.08 & .45 & & & \\
\hline & Senior/Other(d) & 371 & 4.14 & .43 & & & \\
\hline & Total & 706 & 4.10 & .42 & & & \\
\hline \multirow{5}{*}{ Collaboration } & First-year/freshman & 39 & 4.10 & .43 & \multirow{5}{*}{1.677} & \multirow{5}{*}{.171} & \\
\hline & Sophomore & 135 & 4.02 & .43 & & & \\
\hline & Junior & 161 & 4.12 & .45 & & & \\
\hline & Senior/Other & 371 & 4.12 & .45 & & & \\
\hline & Total & 706 & 4.10 & .44 & & & \\
\hline \multirow{5}{*}{ Common Purpose } & First-year/freshman & 39 & 4.10 & .39 & \multirow{5}{*}{2.110} & \multirow{5}{*}{.098} & \\
\hline & Sophomore & 135 & 4.02 & .41 & & & \\
\hline & Junior & 161 & 4.08 & .47 & & & \\
\hline & Senior/Other & 371 & 4.13 & .44 & & & \\
\hline & Total & 706 & 4.10 & .44 & & & \\
\hline \multirow{5}{*}{ Controversy with Civility } & First-year/freshman & 39 & 3.89 & .48 & \multirow{5}{*}{.748} & \multirow{5}{*}{.524} & \\
\hline & Sophomore & 135 & 3.90 & .40 & & & \\
\hline & Junior & 161 & 3.97 & .45 & & & \\
\hline & Senior/Other & 371 & 3.92 & .43 & & & \\
\hline & Total & 706 & 3.92 & .43 & & & \\
\hline \multirow{5}{*}{ Group Values Total } & First-year/freshman & 39 & 4.02 & .38 & \multirow{5}{*}{1.369} & & \\
\hline & Sophomore & 135 & 3.97 & .35 & & & \\
\hline & Junior & 161 & 4.05 & .39 & & .251 & \\
\hline & Senior/Other & 371 & 4.04 & .38 & & & \\
\hline & Total & 706 & 4.03 & .38 & & & \\
\hline
\end{tabular}




\begin{tabular}{|c|c|c|c|c|c|c|c|}
\hline \multirow{5}{*}{ Citizenship } & First-year/freshman & 39 & 4.07 & .55 & \multirow{5}{*}{2.158} & \multirow{5}{*}{.092} & \\
\hline & Sophomore & 135 & 3.99 & .53 & & & \\
\hline & Junior & 161 & 4.11 & .59 & & & \\
\hline & Senior/Other & 371 & 4.13 & .52 & & & \\
\hline & Total & 706 & 4.10 & .54 & & & \\
\hline \multirow{5}{*}{ Change } & First-year/freshman & 39 & 3.71 & .49 & \multirow{5}{*}{2.349} & \multirow{5}{*}{.071} & \\
\hline & Sophomore & 135 & 3.73 & .46 & & & \\
\hline & Junior & 161 & 3.83 & .53 & & & \\
\hline & Senior/Other & 371 & 3.85 & .51 & & & \\
\hline & Total & 706 & 3.81 & .50 & & & \\
\hline \multirow{5}{*}{ community values Total } & $\begin{array}{l}\text { First-year/ } \\
\text { freshman(a) }\end{array}$ & 39 & 3.87 & .45 & \multirow{5}{*}{$2.824^{*}$} & \multirow{5}{*}{.038} & \multirow{5}{*}{$c, d>a, b$} \\
\hline & Sophomore(b) & 135 & 3.85 & .45 & & & \\
\hline & Junior(c) & 161 & 3.96 & .49 & & & \\
\hline & Senior/Other(d) & 371 & 3.97 & .45 & & & \\
\hline & Total & 706 & 3.94 & .46 & & & \\
\hline \multirow{5}{*}{ Omnibus total } & $\begin{array}{l}\text { First-year/ } \\
\text { freshman(a) }\end{array}$ & 39 & 4.02 & .36 & \multirow{5}{*}{$2.782^{*}$} & \multirow{5}{*}{.040} & \multirow{5}{*}{$a, c, d>b$} \\
\hline & Sophomore(b) & 135 & 3.95 & .35 & & & \\
\hline & Junior(c) & 161 & 4.04 & .40 & & & \\
\hline & Senior/Other(d) & 371 & 4.06 & .38 & & & \\
\hline & Total & 706 & 4.03 & .38 & & & \\
\hline
\end{tabular}

${ }^{*} p<.05,{ }^{* *} p<.01,{ }^{* * *} p<.001$

Collegiate Experiences. Students who responded that they participated in extracurricular organizations/ clubs while in college scored relatively higher in individual values total of leadership development outcomes, showing a significant difference $(p<.05$, table 4). There was also a significant difference in the consciousness of self, a sub-variable of individual values $(p<.05)$. Those who participated in extracurricular organizations/clubs also scored relatively higher in the group values total, showing a significant difference $(p<.05)$, and the same trend was observed in collaboration and common purpose. In the community values total and citizenship, students who participated in extracurricular organizations/ clubs scored relatively higher than those who did not, showing a significant difference $(p<.05)$. It can be seen that the difference in the leadership development (SRLS-R2), according to experiences of extracurricular organizations/clubs while in college, was higher for 'Yes' than 'No' $(p<.05)$. 
Table 4

Differences in Leadership Development by Extracurricular Organizations/Clubs

\begin{tabular}{|c|c|c|c|c|c|c|}
\hline & Q6 1 & $\mathbf{N}$ & M & SD & $\mathrm{t}$ & p \\
\hline \multirow{2}{*}{ Consciousness of Self } & Yes & 453 & 3.84 & .52 & \multirow{2}{*}{$2.354^{*}$} & \multirow{2}{*}{.019} \\
\hline & No & 253 & 3.74 & .51 & & \\
\hline \multirow{2}{*}{ Congruence } & Yes & 453 & 4.23 & .48 & \multirow{2}{*}{1.777} & \multirow{2}{*}{.076} \\
\hline & No & 253 & 4.16 & .51 & & \\
\hline \multirow{2}{*}{ Commitment } & Yes & 453 & 4.44 & .47 & \multirow{2}{*}{1.799} & \multirow{2}{*}{.072} \\
\hline & No & 253 & 4.37 & .48 & & \\
\hline \multirow{2}{*}{ Individual Values Total } & Yes & 453 & 4.13 & .42 & \multirow{2}{*}{$2.369^{*}$} & \multirow{2}{*}{.018} \\
\hline & No & 253 & 4.05 & .42 & & \\
\hline \multirow{2}{*}{ Collaboration } & Yes & 453 & 4.15 & .45 & \multirow{2}{*}{$4.214^{\star \star \star}$} & \multirow{2}{*}{.000} \\
\hline & No & 253 & 4.01 & .42 & & \\
\hline \multirow{2}{*}{ Common Purpose } & Yes & 453 & 4.16 & .45 & \multirow{2}{*}{$4.950^{\star \star \star}$} & \multirow{2}{*}{.000} \\
\hline & No & 253 & 3.99 & .39 & & \\
\hline \multirow{2}{*}{ Controversy with Civility } & Yes & 453 & 3.95 & .44 & \multirow{2}{*}{1.838} & \multirow{2}{*}{.066} \\
\hline & No & 253 & 3.88 & .43 & & \\
\hline \multirow{2}{*}{ Group Values Total } & Yes & 453 & 4.07 & .38 & \multirow{2}{*}{$4.097^{* \star *}$} & \multirow{2}{*}{.000} \\
\hline & No & 253 & 3.95 & .35 & & \\
\hline \multirow{2}{*}{ Citizenship } & Yes & 453 & 4.18 & .54 & \multirow{2}{*}{$5.252^{* \star *}$} & \multirow{2}{*}{.000} \\
\hline & No & 253 & 3.96 & .51 & & \\
\hline \multirow{2}{*}{ Change } & Yes & 453 & 3.84 & .51 & \multirow{2}{*}{1.610} & \multirow{2}{*}{.108} \\
\hline & No & 253 & 3.77 & .49 & & \\
\hline \multirow{2}{*}{ community values Total } & Yes & 453 & 3.99 & .46 & \multirow{2}{*}{$3.727^{* \star *}$} & \multirow{2}{*}{.000} \\
\hline & No & 253 & 3.85 & .44 & & \\
\hline Omnibustotal & Yes & 453 & 4.07 & .38 & $378^{* * * *}$ & ( \\
\hline Ummidus total & No & 253 & 3.96 & .36 & 3.148 & .000 \\
\hline
\end{tabular}

${ }^{*} p<.05,{ }^{* *} p<.01,{ }^{* * *} p<.001$

Pre-collegiate Experiences. Students who participated in extracurricular activities while in high school scored relatively higher in individual values total (See table 5$)$, showing a significant difference $(p<.05)$. In the sub-variables, congruence and commitment were also significant differences. Those who participated in extracurricular activities while in high school also scored higher in the group values total, showing a significant difference $(p<.05)$, and all sub-variables, collaboration, common purpose, and controversy with civility, were also significant differences. In the community values total, students who participated in extracurricular activities while in high school also scored higher than those who did not, showing a significant difference $(p<.05)$. A significant difference was also shown in citizenship, a sub-variable of community values $(p<.05)$. Overall, those who participated in extracurricular organizations/clubs in high school scored higher significantly on the SRLS $(p<.05)$. 
Table 5

Differences in Leadership Development by High School Extracurricular Activity

\begin{tabular}{|c|c|c|c|c|c|c|}
\hline Q14 1 & & $\mathbf{N}$ & M & SD & $t$ & $p$ \\
\hline \multirow{2}{*}{ Consciousness of Self } & Yes & 598 & 3.81 & .50 & \multirow{2}{*}{1.022} & \multirow{2}{*}{.307} \\
\hline & No & 104 & 3.76 & .59 & & \\
\hline \multirow{2}{*}{ Congruence } & Yes & 598 & 4.23 & .46 & \multirow{2}{*}{$2.583^{* *}$} & \multirow{2}{*}{.010} \\
\hline & No & 104 & 4.10 & .61 & & \\
\hline \multirow{2}{*}{ Commitment } & Yes & 598 & 4.43 & .46 & \multirow{2}{*}{$2.469^{\star}$} & \multirow{2}{*}{.014} \\
\hline & No & 104 & 4.30 & .57 & & \\
\hline \multirow{2}{*}{ Individual Values Total } & Yes & 598 & 4.11 & .40 & \multirow{2}{*}{$2.215^{*}$} & \multirow{2}{*}{.027} \\
\hline & No & 104 & 4.01 & .53 & & \\
\hline \multirow{2}{*}{ Collaboration } & Yes & 598 & 4.12 & .44 & \multirow{2}{*}{$2.856^{* *}$} & \multirow{2}{*}{.004} \\
\hline & No & 104 & 3.98 & .48 & & \\
\hline \multirow{2}{*}{ Common Purpose } & Yes & 598 & 4.13 & .42 & \multirow{2}{*}{$4.397^{* \star *}$} & \multirow{2}{*}{.000} \\
\hline & No & 104 & 3.93 & .48 & & \\
\hline \multirow{2}{*}{ Controversy with Civility } & Yes & 598 & 3.94 & .43 & \multirow{2}{*}{$2.178^{*}$} & \multirow{2}{*}{.030} \\
\hline & No & 104 & 3.84 & .43 & & \\
\hline \multirow{2}{*}{ Group Values Total } & Yes & 598 & 4.05 & .37 & \multirow{2}{*}{$3.603^{* \star *}$} & \multirow{2}{*}{.000} \\
\hline & No & 104 & 3.91 & .40 & & \\
\hline \multirow{2}{*}{ Citizenship } & Yes & 598 & 4.13 & .53 & \multirow{2}{*}{$4.019^{* \star *}$} & \multirow{2}{*}{.000} \\
\hline & No & 104 & 3.90 & .58 & & \\
\hline \multirow{2}{*}{ Change } & Yes & 598 & 3.81 & .51 & \multirow{2}{*}{.000} & \multirow{2}{*}{1.000} \\
\hline & No & 104 & 3.81 & .48 & & \\
\hline \multirow{2}{*}{ community values Total } & Yes & 598 & 3.95 & .46 & \multirow{2}{*}{$2.106^{\star}$} & \multirow{2}{*}{.036} \\
\hline & No & 104 & 3.85 & .46 & & \\
\hline Omnibuc total & Yes & 598 & 4.05 & .37 & $2062^{* *}$ & 003 \\
\hline Omnıbus total & No & 104 & 3.93 & .43 & 2.902 & .003 \\
\hline
\end{tabular}

${ }^{*} p<.05,{ }^{* *} p<.01,{ }^{* * *} p<.001$

Correlational Analysis. According to the correlation analysis of related variables (Table 6) for participating in extracurricular organizations/clubs while in college, there was a significant positive correlation with individual values total $(r=.089, p<.05)$ and group values total $(r=.153, p<.05)$. There was also a significant positive correlation with community values total $(r=.139, p<.05)$. Overall, there was a significant positive correlation with leadership development $(r=.140, p<.05)$.

Extracurricular activities while in high school showed a significant positive correlation with individual values total $(r=.083, p<.05)$. There was also a significant positive correlation with group values total $(r=.135, p<.05)$, as well as a positive correlation with community values total $(r=.079, p<.05)$. Overall, there was a significant positive correlation $(r=.111$, $p<.05)$ with the omnibus of leadership development (SRLS-R2). 
Table 6

Correlation Analysis of Related Variables

\begin{tabular}{|c|c|c|c|c|c|c|}
\hline & $\begin{array}{l}\text { Q6_1: } \\
\text { Extra clubs }\end{array}$ & $\begin{array}{l}\text { Q14_1: } \\
\text { HS Extra } \\
\text { activities }\end{array}$ & $\begin{array}{l}\text { Individual } \\
\text { Values } \\
\text { Total }\end{array}$ & $\begin{array}{l}\text { Group } \\
\text { Values } \\
\text { Total } \\
\end{array}$ & $\begin{array}{l}\text { community } \\
\text { values Total }\end{array}$ & total \\
\hline Q6_1: Extra clubs & 1 & & & & & \\
\hline \multirow{2}{*}{ Q14_1: HS Extra activities } & $.325^{\star * *}$ & 1 & & & & \\
\hline & .000 & & & & & \\
\hline \multirow{2}{*}{ Individual Values Total } & $.089 *$ & $.083^{*}$ & 1 & & & \\
\hline & .018 & .027 & & & & \\
\hline \multirow{2}{*}{ Group Values Total } & $.153^{* \star *}$ & $.135^{* \star *}$ & $.745^{\star \star \star}$ & 1 & & \\
\hline & .000 & .000 & .000 & & & \\
\hline \multirow{2}{*}{ community values Total } & $.139 * * \star$ & $.079 *$ & $.689 * \star \star$ & $.813^{* \star *}$ & 1 & \\
\hline & .000 & .036 & .000 & .000 & & \\
\hline \multirow[t]{2}{*}{ Omnibus } & 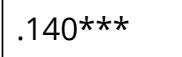 & $.111 * *$ & $.890 * * *$ & $.942 * * *$ & $.904 * \star \star$ & 1 \\
\hline & .000 & .003 & .000 & .000 & .000 & \\
\hline
\end{tabular}

${ }^{*} p<.05,{ }^{* *} p<.01,{ }^{* * *} p<.001$

\section{Discussion}

General Characteristics. Gender and class level were positively associated with student leadership development. Women scored higher than men in the congruence and commitment, sub-variables of the individual values on the leadership development (SRLS-R2), and showed significant differences $(p<.05$, table 2 ) between groups. This finding reflects previous research of Haber and Komives (2009). They noted that the predictors used in the regression analysis were more relevant for women than men in the individual value of leadership development. This could be because women may be more intentional about their leadership development and may seek out opportunities to develop their leadership skills. However, the omnibus' total indicates that the difference in the SRLS-R2 according to gender is not significant.
At the class level, seniors and juniors were relatively high on leadership outcomes, and the sophomores were relatively low. Specifically, the consciousness of self in individual values showed a significant difference $(P<.05$, table 3$)$. This result is consistent with previous research (Pascarella \& Terenzini, 2005) that upperclassmen continue to show higher leadership development outcomes than their firstyear counterparts. This is important as it provides some empirical support for the "value-added effect" of college on students; that is, the study's results suggest that educational benefits may cascade over time.

\section{Experiences of Extracurricular Activity.} Participation in extracurricular activities exerted a direct positive effect on leadership development outcomes. This finding is consistent with the previous study of Foreman and Retallick (2013) on the 
importance of participating in extracurricular clubs and organizations. They noticed that involvement in these activities had a strong relationship with leadership development. When students have experiences participating in extracurricular organizations/clubs while in college, their group and community values of leadership development are relatively higher than those who do not have experience. Specifically, common purpose and citizenship showed significant differences between groups $(p<.05$, table 4 .).

While in high school, if students participate in extracurricular activities, they have higher leadership outcomes in most of the values except 'Change.' Specifically, there was a significant difference in group values total $(p<.05$, table 5$)$ and all sub-variables of group values, which were: collaboration, common purpose, and controversy with civility.

\section{Correlation to Leadership Development}

Outcomes. The study examined the correlation between pre-collegiate and collegiate experiences on leadership outcomes. There was a significant positive correlation between the experience of participating in extracurricular organizations/clubs and leadership training and individual, group, and community values of leadership development outcomes.

Additionally, participating in extracurricular activities while in high school showed a significant positive correlation with all leadership values. Theoretically speaking, student development is the product of the multidimensional and reciprocal interaction between an individual and his/her environment. The present findings show the relationship between participation in extracurricular activities and students' leadership developmental outcomes.

In the same context, these results support Astin's involvement theory regarding the core concepts such as 'input,' 'environment,' and 'outcome' for student development. He suggests the concept of student involvement as a pedagogical theory to examine how educational programs and policies are related to student development (Astin, 1999). These findings provide an important foundation from which to increase the understanding of patterns of student involvement in extracurricular activities and their influence on critical leadership development outcomes.

\section{Conclusions}

The current study revealed the relationship between extracurricular activity and leadership development and how extracurricular involvement affected college students' leadership development relating to the individual, group, and community values of the Socially Responsible Leadership Scale (SRLS-R2). The main findings are as follows:

First, extracurricular activities significantly affected students' individual, group, and community values of leadership development. Women had relatively higher leadership development than men and showed significant differences in congruence, commitment, and citizenship. Senior students indicated relatively higher leadership development than sophomores. In addition, both high school and college students who participated in extracurricular organizations/clubs showed relatively higher leadership development outcomes than those who did not have these experiences. Simonsen and colleagues (2014) insisted that students should be encouraged to be active in student activities and organization participation during high school and possibly focus more on developing their leadership potential. Both college and secondary educators who supervise student activities should be challenged to engage student participation more explicitly and intentionally for potential leadership development.

Second, educators should be challenged to enhance students' participation in extracurricular activities for their leadership development. There were significant positive correlations between both pre-collegiate 
and collegiate participation in extracurricular organizations/clubs and all individual, group, and community values of leadership development outcomes. The results of this study support the critical role of extracurricular activities on individual, group, and community values on student leadership development. Data in this study represented patterns that emerged during pre-college and college experiences. Research would be beneficial that examined how these patterns evolved throughout college to better understand how patterns influence students over time.

As the use of the Social Change Model (Higher Education Research Institute, 1996) of leadership development continues to expand both across educational contexts and globally, so does the need to understand how best to advance the theory, research, and practices that inform it. The primary vehicle for this is the SRLS. This study offered awareness into the nature of the measurement tool, considerations for its use, and results from validation studies attempting to expand the understanding of how it best functions. These perceptions have direct implications for research and assessment as well as future theory building.

Moreover, researchers should consider collecting data to capture other dimensions of extracurricular activity involvement. For example, studies should collect longitudinal and multi-informant data from adults and parents instead of relying on students' reports to determine levels of leadership development and involvement. Additional research is also required to explore factors related to student activity and organization participation that may be positively and negatively linked to leadership development. Specifically, researchers should explore whether or not co-curricular activities have similar effects and continue investigating relationships between student activity participation and leadership constructs among other populations. 


\section{References}

Astin, A. W. (1984). Student involvement: A developmental theory for higher education. Journal of College Student Development, 40(5), 518-529. https://www.researchgate.net/publication/220017441_Student_ Involvement_A_Development_Theory_for_Higher_Education

Astin, A. W. (1993). What matters in college? Four critical years revisited. San Francisco, CA: Jossey-Bass.

Astin, A. W. (1999). Student involvement: A developmental theory for higher education. Journal of College Student Development, 40(5), 518-529.

Astin, H. S., \& Astin, A. W. (1996). A social change model of leadership development: Guidebook (ver. III). Higher Education Research Institute, University of California, Los Angeles. https://www.heri.ucla.edu/PDFs/pubs/ ASocialChangeModelofLeadershipDevelopment.pdf

Black, K. (2010). Business statistics: Contemporary decision making (6th ed.). Hoboken, NJ: John Wiley \& Sons.

Boatman, S. A. (1999). The leadership audit: A process to enhance the development of student leadership. NASPA Journal, 37(1), 325-36. https://doi.org/10.2202/1949-6605.1100

Buschlen, E. L., \& Johnson, M. (2014). The effects of an introductory leadership course on socially responsible leadership, examined by age and gender, Journal of Leadership Education. 13(1), 31-45. doi: 10.12806/V13/ I1/R3

Dugan, J. P. (2006a). SRLS-Rev2: The second revision of SRLS. College Park, MD: National Clearinghouse for Leadership Programs.

Dugan, J. P. (2006b). Involvement and leadership: A descriptive analysis of socially responsible leadership. Journal of College Student Development, 47(3), 335-343. doi:10.135/csd.2006.0028

Dugan, J. P., \& Komives, S. R. (2007). Developing leadership capacity in college students: Findings from a national study. A Report from the multi-institutional study of leadership. College Park, MD: National Clearinghouse for Leadership Programs. https://static1.squarespace.com/static/5873de271e5b6c645d5b5ac3/t/58d567c 32994ca0cfee0ed74/1490380770799/2006+MSL+National+Report\%5B5686\%5D.pdf

Eagly, A. H. (2007). Female leadership advantage and disadvantage: Resolving the contradictions. Psychology of Women Quarterly, 31, 1-12. https://doi.org/10.1111/j.1471-6402.2007.00326.x

Ewing, C. J., Bruce, A. J., \& Ricketts, G. K. (2009). Effective leadership development for undergraduates: How important is active participation in collegiate organizations? Journal of Leadership Education, 7(3), 118-132. doi:10.12806/V7/I3/RF3

Foreman, A. E., \& Retallick, S. M. (2013). Using involvement theory to examine the relationship between undergraduate participation in extracurricular activities and leadership development. Journal of Leadership Education, 12(2), 56-73. doi: 10.12806/V12/I2/R4

Haber, P. (2012). Perceptions of leadership: An examination of college students' understandings of the concept of leadership. Journal of Leadership Education, 11(2), 26-50. doi: 10.12806/V11/I2/RF2

Haber, P., \& Komives, S. R. (2009). Predicting the individual values of the social change model of leadership development: The role of college students' leadership involvement experiences. Journal of Leadership Education, 7(3), 133-166. doi:10.12806/V7/I3/RF4 
Hancock, D., Dyk, H. P., \& Jones, K. (2012). Adolescent involvement in extracurricular activities: Influences on leadership skills. Journal of Leadership Education, 11(1), 84-101. doi:10.12806/V11/I1/RF5

Hannah, S. T., Avolio, B. J., Luthans, F., \& Harms, P. D. (2008). Leadership efficacy: Review and future directions. The Leadership Quarterly, 19(6), 669-692. doi: 10.1016/j.leaqua.2008.09.007

Higher Education Research Institute (1996). A social change model of leadership development: Guidebook version III. College Park, MD: National Clearinghouse for Leadership Programs.

Huang, Y., \& Chang, S. (2004). Academic and co-curricular involvement: Their relationship and the best combinations for student growth. Journal of College Student Development, 45, 391-406. doi:10.1353/ csd.2004.0049

Kezar, A., \& Moriarty, D. (2000). Expanding our understanding of student leadership development: A study exploring gender and ethnic identity. Journal of College Student Development, 41, 55-68

Komives, S. R., Dugan, J. P., Owen, J. E., Slack, C., Wagner, W., \& Associates. (2011). The handbook for student leadership development (2nd ed.). San Francisco, CA: John Wiley \& Sons.

Komives, S. R., Wagner, W., \& Associates. (2009). Leadership for a better world: Understanding the social change model of leadership development. San Francisco, CA: John Wiley \& Sons.

Linver, M. R., Roth, J. L., \& Brooks-Gunn, J. (2009). Patterns of adolescents' participation in organized activities: are sports best when combined with other activities?. Developmental psychology, 45(2), 354-367. https://doi.org/10.1037/a0014133

Pascarella, E. T., \& Terenzini, P. T. (2005). How college affects students: A third decade of research. JosseyBass, CA. 534-545.

Rost, J. C. (1991). Leadership for the twenty-first century. Westport, CT: Praeger.

Rubin, R. S., Bommer, W. H. \& Baldwin, T. T. (2002). Using extracurricular activity as an indicator of interpersonal skill: Prudent evaluation or recruiting malpractice? Human Resource Management, 41, 441454. https://doi.org/10.1002/hrm.10053

Rutherford, T. A., Townsend, C. D., Briers, G. E., Cummins, R., \& Conrad, C. R. (2002). Leadership self-perceptions of WLC participants. Journal of Agricultural Education, 43 (2), 22-33. doi: 10.5032/ jae.2002.02022

Simonsen, C. J., Velez, J. J., Foor, M. R., Birkenholz, J. R., Foster, D. D., Wolf, J. K., \& Epps, B. R., (2014). A multiinstitutional examination of the relationships between high school activity involvement and leadership characteristics. Journal of Agricultural Education, 55(1), 200-214. doi: 10.5032/jae.2014.01200

Smith, J. L., \& Chenoweth, D. J. (2015). The contributions of student organization involvement to students' self-assessments of their leadership traits and relational behaviors. American Journal of Business Education, 8(4), 279-288. https://doi.org/10.19030/ajbe.v8i4.9422

Strayhorn, T. L. (2008). How college students' engagement affects personal and social learning outcomes, Journal of College \& Character, 10(2). 1-13. https://www.tandfonline.com/doi/pdf/10.2202/1940-1639.1071

World Education Services (2019, October). Why Extracurricular Activities Are Important While Studying. https://www.wes.org/advisor-blog/extracurricular-activities-for-education-abroad/ 
Zacherman, A., \& Foubert, J. (2014). The relationship between engagement in cocurricular activities and academic performance: Exploring gender differences. Journal of Student Affairs Research and Practice, 51(2), 157-169. http://dx.doi.org/10.1515/jsarp-2014-0016 